\title{
DOE/PC/90050-T5
}

"Design, Synthesis, and Characterization of Novel FineParticle, Unsupported Catalysts for Coal Liquefaction"

\author{
DRAFT \\ Technical Progress Report \\ $10 / 26 / 91-1 / 25 / 92$ \\ Michael T. Klein \\ Principal Investigator \\ and \\ Henry C. Foley \\ Co-investigator
}

$\mathrm{DOE} / \mathrm{PC} / 90050--\mathrm{T5}$

DE92 015539

Center for Catalytic Science and Technology

Department of Chemical Engineering

University of Delaware

Newark, Delaware 19716

Date Published:

March 23, 1992

Contract Number: DE-AC22-90PC 90050

Prepared for Department of Energy

U. S. DOE PATENT CLEARANCE IS NOT REQUIRED PRIOR TO PUBLICATION OF THIS DOCUMENT 


\section{Catalyst Synthesis}

\section{A. Fine-Particle Iron Sulfides}

An investigation aimed at devising a procedure for preparing alkyl- or aryl-capped iron sulfide particles has been initiated. An initial attempt (S-31) involved the competitive reaction of thiophenol ( $\mathrm{PhSH}$ ) and sodium sulfide (Na2S) with $\mathrm{Fe}(\mathrm{II})$. In this procedure (similar to that of Herron, Wang, and Eckert for CdS particle synthesis ${ }^{1}$ ), a methanol/water solution containing $\mathrm{Fe}\left(\mathrm{NH}_{4}\right)_{2}\left(\mathrm{SO}_{4}\right)_{2} \cdot 6 \mathrm{H}_{2} \mathrm{O}$ was added with stirring to a solution containing Na2S and $\mathrm{PhSH}$ in methanol/water. As shown in Table 1, the ratio [PhSH]/[Na2S] was varied between 0 and 10 in preparations S-31A, S-31B, and S-31C. The idea was that $\mathrm{PhS}^{-}$would cap the growth of the iron sulfide particles formed by reaction of $\mathrm{Fe}(\mathrm{II})$ and $\mathrm{S}^{2-}$, and so by varying the ratio $[\mathrm{PhSH}] /\left[\mathrm{Na}_{2} \mathrm{~S}\right]$ some size control of the iron sulfide particles prepared could be attained. SEM examination of the particles formed by preparations S-31A, B, and C showed no significant difference in their size.

\section{Table 1}

$\mathrm{Fe}$ cmpda $\mathrm{Na}_{2} \mathrm{~S} \cdot 9 \mathrm{H}_{2} \mathrm{O}^{b} \quad \mathrm{PhSH}$ [PhSH]:[Na2S]

Particle

$$
\text { (mmol) (mmol) (mmol) (molar) size }(\mathrm{mm})
$$
S-31A
0.5
0.5
0
0

S-31B

0.5

0.25

0.5

$2: 1$

$0.5-$

a $\mathrm{Fe} \mathrm{cmpd}=\mathrm{Fe}\left(\mathrm{NH}_{4}\right)_{2}\left(\mathrm{SO}_{4}\right)_{2} \cdot 6 \mathrm{H}_{2} \mathrm{O}$, in $20 \mathrm{ml} 66 \%(\mathrm{~V} / \mathrm{v})$ aq $\mathrm{MeOH}$

b $\mathrm{Na}_{2} \mathrm{~S} \cdot 9 \mathrm{H}_{2} \mathrm{O}$ and $\mathrm{PhSH}$ in $20 \mathrm{ril} 66 \%(\mathrm{~V} / \mathrm{V})$ aq $\mathrm{MeOH}$ 
It is possible that the phenyl group of thiophenol is not bulky enough to prevent thiolate bridging and consequent particle size growth of the metal sulfide. To investigate this possibility, 1-adamantanethiol, which incorporates more steric bulk than thiophenol, has been synthesized from 1 bromoadamantane. The bulkier 1 -adamantanethiol will be used in the next attempt to prepare capped iron sulfide particles.

\section{B. Molecular Catalysts/Precursors}

A ferredoxin analog of the formula $\left(\mathrm{Bu}_{4} \mathrm{~N}\right)_{2}\left[\mathrm{Fe}_{4} \mathrm{~S}_{4}(\mathrm{SPh})_{4}\right]$ was prepared following the synthesis outlined by Holm, et al. ${ }^{2}$ Approximately $2 \mathrm{~g}$ of this material has been prepared. The structure of the material is as follows:

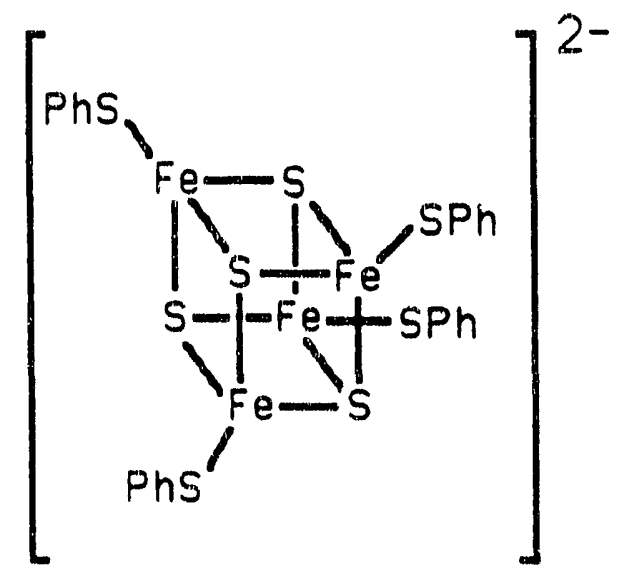

After the compound is characterized, its suitability as a catalyst and/or fineparticle iron sulfide precursor will be investigated.

\section{Bench-Top Reactor Tests}

Reactor test T-3, using the bench-top glass reactor, examined the decomposition of the model compound DBE using iron sulfide particles generated by thermal, in-situ decomposition of $\mathrm{Fe}(\mathrm{CO})_{2}\left(\mathrm{PPh}_{3}\right) \mathrm{CS}_{2}$ in the presence of a sulfur source. In this test, $0.50 \mathrm{~g}(0.7 \mathrm{mmol})$ of $\mathrm{Fe}(\mathrm{CO})_{2}\left(\mathrm{PPh}_{3}\right) \mathrm{CS}_{2}, 0.42 \mathrm{~g}$ (14 mmol) $\mathrm{PPh}_{3}$, and $1.81 \mathrm{~g}(8 \mathrm{mmol})$ of PhSSPh (phenyl disulfide) were added to a refluxing $\left(250.5^{\circ} \mathrm{C}\right)$ solution of $30 \mathrm{~g} \mathrm{THQ}$ (tetrahydroquinoline) and $10 \mathrm{~g} \mathrm{DBE}$ (dibenzylether). These conditions were 
similar to those of previous tests done in our tubing bomb reactors, except scaled up by a factor of ten. Also, PhSSPh replaced $\mathrm{CS}_{2}$ as the sulfur source since the former is higher boiling, and thus would tend to remain in the liquid reaction system. The catalyst precursor decomposed rapidly upon addition to the $250.5^{\circ} \mathrm{C}$ solution to give a fine black precipitate. DBE conversion after 180 min reaction time was $65 \%$, but a subsequent reactor test (T-4) done using the same operating conditions as T-3 but without addition of $\mathrm{Fe}(\mathrm{CO})_{2}\left(\mathrm{PPh}_{3}\right) \mathrm{CS}_{2}$ or $\mathrm{PPh}_{3}$, showed that this level of conversion is entirely due to catalytic action of the phenyl disulfide. Future bench-top reactor runs will use $\mathrm{H}_{2} \mathrm{~S}$ as a sulfur source.

Reactor tests $T-5, T-6$, and $T-7$ investigated the size of the catalyst particles formed by thermal decomposition of the catalyst precursors $\mathrm{Fe}_{\theta}(\mathrm{CO})_{2}\left(\mathrm{PPh}_{3}\right)_{2} \mathrm{CS}_{2}, \mathrm{Fe}(\mathrm{CO})_{4} \mathrm{PPh}_{3}$, and $\mathrm{F} \theta(\mathrm{CO})_{3}\left(\mathrm{PPh}_{3}\right)_{2}$, respectively. In $\mathrm{T}$ $5,0.25 \mathrm{~g}(0.35 \mathrm{mmol})$ of the precursor $\mathrm{Fe}(\mathrm{CO})_{2}\left(\mathrm{PPh}_{3}\right)_{2} \mathrm{CS}_{2}$ and $0.21 \mathrm{~g}(0.8$ $\mathrm{mmol})$ of triphenylphosphine were added to a refluxing $\left(250^{\circ} \mathrm{C}\right)$ solution of 30 $\mathrm{ml}$ tetrahydroquinoline (THQ) and $10 \mathrm{ml}$ dibenzylether (DBE). Upon addition, the precursor decomposed to give a fine, black precipitate. In T. $6,0.25 \mathrm{~g}(0.6$ $\mathrm{mmol})$ of $\mathrm{Fe}(\mathrm{CO})_{4} \mathrm{PPh}_{3}$ and $0.5 \mathrm{~g}(2.3 \mathrm{mmol})$ phenyldisulfide were added to 30 $\mathrm{ml}$ refluxing $\left(242^{\circ} \mathrm{C}\right) \mathrm{THQ}$, forming a black precipitate similar in appearance to that of T-5. Test $\mathrm{T}-7$ examined $\mathrm{Fe}(\mathrm{CO})_{3}\left(\mathrm{PPh}_{3}\right)_{2}$ under the same conditions as $T-6$. The particles formed from all three catalyst precursors by this thermal decomposition method in refluxing solvent were all relatively large $(5-25 \mathrm{~mm})$. The elemental composition of the particles has not been determiried.

\section{Catalyst Testing}

\section{A. Shaken Micro-Batch Reactors}

Our recent model compound work has been confined to the reaction of dibenzyl ether in a hydrogen donating solvent (Tetralin). We are now expanding our scope to include a new model compound, napthyl bibenzyl methane (NBBM), which has been examined in the literature as a model compound for the purpose of modeling coal liquefaction 2.

The model compound NBBM was also reacted thermally and in the presence of a catalyst precursor $\left(\mathrm{Fe}(\mathrm{CO})_{2}\left(\mathrm{PPh}_{3}\right)_{2} \mathrm{CS}_{2}\right.$ in this case), at a 
temperature of $420^{\circ} \mathrm{C}$ for 60 minutes. In this case, the conversion of NBBM was $10 \%$ without addition of the precursor, and $15 \%$ with the addition of the precursor. In subsequent reactions, however, it was found that at this high temperature $\left(420^{\circ} \mathrm{C}\right)$, the walls of the stainless steel micro-batch reactor were being sulfided and that the iron sulfide derived from the catalyst precursor was also plating to the reactor walls. To avoid this problem our experimental procedure has been altered. The reactants are now sealed in a $1 \mathrm{~mL}$ glass ampule, and the ampule is placed inside the steel micro-batch reactor and packed with glass wool. The reactor is shaken, as before, during reaction to effect good mixing and catalyst contact in the reaction mixture.

Employing this new experimental procedure, we have pertormed reactions with NBBM in the presence of our iron carbonyl based catalyst precursors. The results are listed in Tables 2 and 3.

\section{Table 2}

\section{Precurser}

$\mathrm{Fe}(\mathrm{CO})_{4} \mathrm{PPh}_{3}$

$\mathrm{Fe}(\mathrm{CO})_{3}\left(\mathrm{PPh}_{3}\right)_{2}$

$\mathrm{Fe}(\mathrm{CO})_{2}\left(\mathrm{PPh}_{3}\right)_{3} \mathrm{CS}_{2}$
Conversion

23.4

The conversions and the relative yields of the products obtained for the three precursors are virtually the same, implying that the active species derived from the precursors are similar or identical species. There is a great deal more information obtained in the relative product yields, but we are attempting to alter out experimental procedure to measure the values of the yields for the products which could not be detected in our initial experiments (See Table 3). In addition, we will be comparing $\mathrm{Fe}(\mathrm{CO}) 5$ as a precursor under similar conditions. When we have obtained this data we will perform a full analysis on the data. 


\section{Table 3}

Relative Product Yields $(x 100)$

$\mathrm{Fe}_{\theta}(\mathrm{CO})_{4} \mathrm{PPh}_{3} \quad \mathrm{Fe}_{\theta}(\mathrm{CO})_{3}\left(\mathrm{PPh}_{3}\right)_{2} \quad \mathrm{Fe}(\mathrm{CO})_{2}\left(\mathrm{PPh}_{3}\right)_{2} \mathrm{CS}_{2}$

\begin{tabular}{|c|c|c|c|}
\hline (0) & 9.7 & 11.8 & 11.4 \\
\hline 0 & 8.3 & 9.5 & 1.0 \\
\hline 5 & -.. & -.- & ... \\
\hline & 1.1 & 1.4 & --. \\
\hline 0,6 & 4.7 & 4.8 & 4.5 \\
\hline & 2.1 & 2.1 & 1.9 \\
\hline & 0.6 & 0.8 & -.- \\
\hline & 0.4 & 0.6 & -.. \\
\hline & 4.8 & 4.8 & 5.4 \\
\hline & $\cdots$ & $\cdots$ & $\cdots$ \\
\hline & 7.7 & 8.2 & 9.4 \\
\hline & 1.7 & 1.7 & -- \\
\hline
\end{tabular}

$\ldots=$ below detection limits 


\section{B. Short Contact Time Reactor}

In previous communications we have reported performing a coal liquefaction run in a pulse-injection CSTR reactor using $\mathrm{Fe}(\mathrm{CO}) 5$ as a catalyst precursor. The coal conversions obtained in this catalytic run, along with the results of a thermal liquefaction run at the same temperature are shown in Figure 1. The conversions calculated for

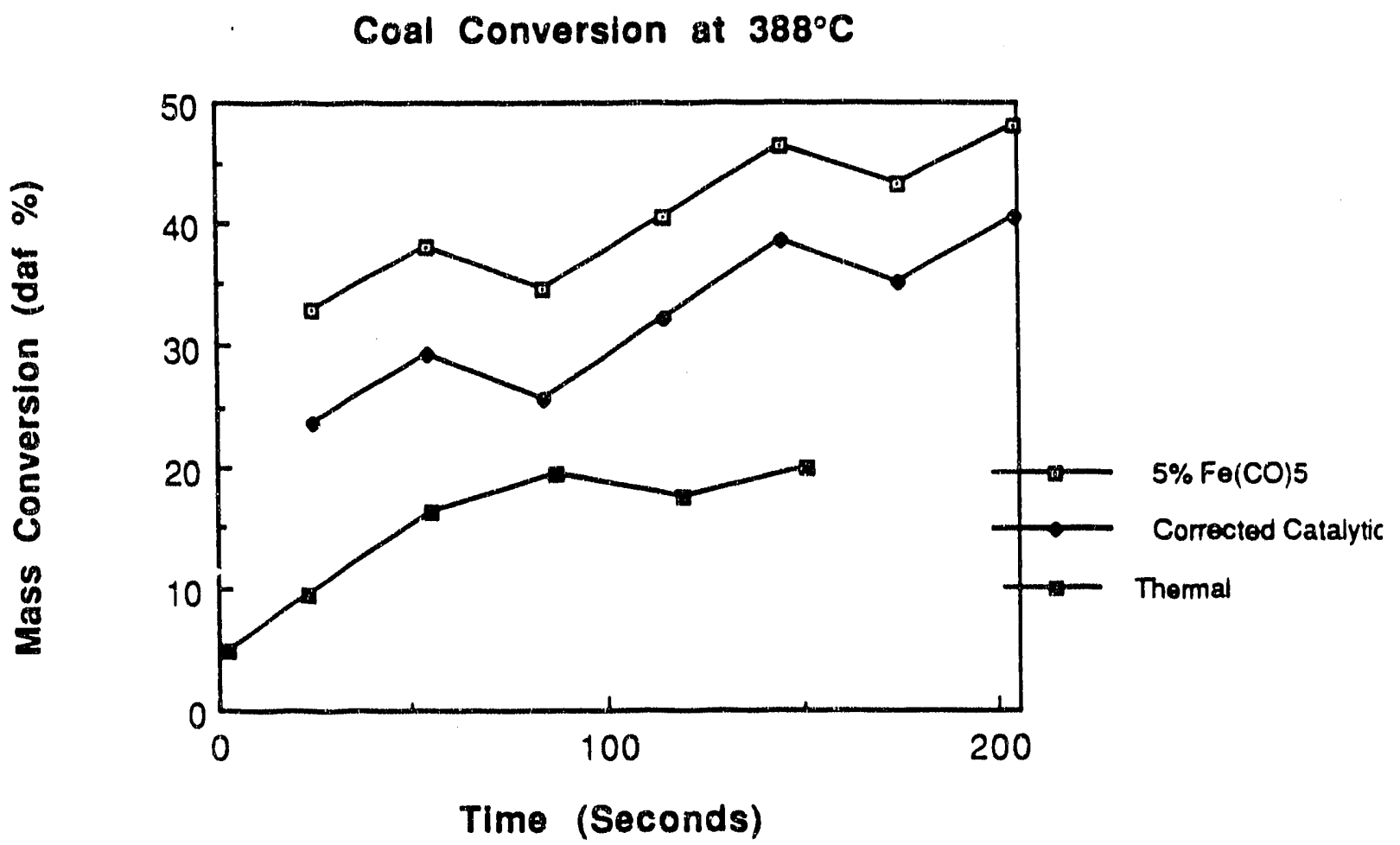

Fiaure 1: Mass conversion of coal at $388^{\circ} \mathrm{C}$ in Tetralin. Tetralin flow $7 \mathrm{~L} / \mathrm{hr}$, $50 \mathrm{~g}$ of Illinois $\# 6$ coal charge, $2.5 \mathrm{~g} \mathrm{Fe}(\mathrm{CO}) 5$. The catalytic conversion assumes that all of the iron from the $\mathrm{Fe}(\mathrm{CO}) 5$ is found in the ash content.

the catalytic run has not been corrected for the addition of the catalyst to the ash. If all of the iron in the catalyst precursor added to the ash it would lower the calculated value of the conversion by approximately $10 \%$. However, even with this lowered conversion, the catalytic run still shows significantly higher conversions than the thermal run. In addition, ${ }^{1}$ H NMR analyses have been carried out on the coal derived liquids from the catalytic and 
thermal runs, but their interpretation is not clear at this time. We plan to test other catalyst precursors for coal liquefaction in the short contact time reactor.

\section{References}

1. Herron, N., Wang, Y., and Eckert, H., "Synthesis and Characterization of Surface-Capped, Size-Quantized CdS Clusters. Chemical Control of Cluster Size", J. Am. Chem. Soc, 1990, 112, 1322-1326.

2. Farcasiu, M., and Smith, C., "Modeling Coal Liquefaction. 1. Decomposition of 4(1-Naphthylmethyl)bibenzyl Catalyzed by Carbon Black", Energy and Fuels, 1991, 5, 8387.

\section{DISCLAIMER}

This report was prepared as an account of work sponsored by an agency of the United States Government. Neither the United States Government nor any agency thereof, nor any of their employees, makes any warranty, express or implied, or assumes any legal liability or responsibility for the accuracy, completeness, or usefulness of any information, apparatus, product, or process disclosed, or represents that its use would not infringe privately owned rights. Reference herein to any specific commercial product, process, or service by trade name, trademark, manufacturer, or otherwise does not necessarily constitute or imply its endorsement, recommendation, or favoring by the United States Government or any agency thereof. The views and opinions of authors expressed herein do not necessarily state or reflect those of the United States Government or any agency thereof. 


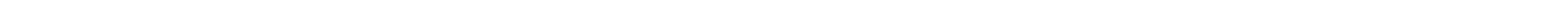




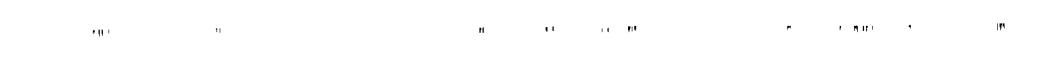

